\title{
Influence of digital banking channels on the number of branches in European Union countries and Serbia
}

\section{Утицај дигиталних банкарских канала на број филијала у земљама Европске уније и Србије}

\author{
Maja Putica * \\ Vojvođanska banka a.d. Novi Sad, \\ majaputica@gmail.com
}

\begin{abstract}
This study analyses the use of digital banking channels in the European Union and Serbia and the effect of their use on the number of branches. The aim of the study is to identify the banking channels, which explain the differences between these countries and to examine the existence of digital channels effect on the variation in the number of branches. The paper applied several statistical methods of multivariate analysis. Using factor analysis, the main factors were identified in the light of clarifying differences between countries, and the multiple linear regression method examined the influence of two independent variables-digital channels, representative for identified factors, on the dependent variable - number of branches. The research results show that there are significant differences between the examined countries in terms of credit card and direct debit services use. The variable that has a significant effect on reducing the number of branches is direct debit services usage.
\end{abstract}

Keywords: number of branches, digital banking channels, multivariate analysis, European Union, Serbia JEL classification: G21, M31

Сажетак: У овом раду анализирана је употреба дигиталних банкарских канала у земљама Европске уније и Србији и ефекат те употребе на број филијала. Циљ студије је да се идентификују банкарски канали који објашњавају разлике између поменутих земаља као и да се испита постојање ефеката одређених дигиталних канала на варијације у броју филијала. У раду је примењено неколико статистичих метода мултиваријационе анализе. Уз помоћ факторске анализе идентификовани су главни фактори у светлу појашњења разлика између земаља, а методом вишеструке линеарне регресије испитан је утицај две независне варијабле - дигитални канали, репрезентативне за идентификоване факторе, на зависну варијаблу - број филијала. Резултати истраживања показују да постоје значајне разлике између испитиваних земаља по питању употребе кредитних картица и директ дебит услуга. Варијабла која има значајан утицај на смањење броја филијала је употреба директ дебит сервиса.

Кључне речи: број филијала, дигитални банкарски канали, мултиваријациона анализа, Европска унија, Србија

JEL класификација: G21, M31

\footnotetext{
Corresponding author
} 


\section{Introduction}

With the digitalization of banking channels, there are changes in the expectations of users of banking products and services, and consequently a transition process, from business focused on achieving the profitability of branches to business, whose primary goal is the satisfaction of the end user of banking products and services. According to Bergendahl and Lindblom (2007), the transition process reduces the cost of business, so that the traditional, so-called offline transactions performed within the banks, are largely replaced by electronic transactions, while the communication with clients is shifted from the branches to electronic banking channels. The transition process from traditional to electronic banking channels began in the 1970s. This was particularly influenced by the online offers of products and services by the new entities in the market, such as service providers and virtual banks, resulting in the gradual loss of importance in the physical presence of banks (Byers \& Lederer, 2001; dos Santos \& Kvangraven, 2017; Jagtiani \& Lemieux, 2018; Holland et al., 1998).

The influence of digitalization of banking channels to the transformation of banking network operations was addressed by many authors, whose research focus was on a different form of branch business, changed relationships between employees and clients, new external and internal appearance of branches and optimal number of employees in them (Yakhlef, 2001; King, 2010; Nitescu, 2015; Moutinho et al., 1997). The role of branches is gradually changing from basic transactional business to advisory banking, giving banks the opportunity to get to know clients and their habits, which adds to the complexity of business processes (Nitiescu, 2015).

In practice, there are different theories as to what factors determine the type of banking channel customers will use.

Sousa et al. (2015) and Howcroft and Beckett (1996) point to the fact that the complexity of the banking product and the volume of transactions may influence the user's preference for a particular banking channel. Thus, they claim that more complex banking activities including activities performed by users on a larger scale cause a greater intensity in using the traditional distribution channel, while medium volume and medium complex activities are most often done through digital channels, as cheaper substitutes. There are also some who view the use of banking channels from other aspects; for instance, Amromin and Chakravorti (2009) argue that the use of electronic forms of payment will only dominate traditional payment methods in the cases of small-value cash transactions. If the transactions are of higher value, then the substitution effect is not expressed.

Morris and Simoff (2013) claim that the number of cash transactions in branches is annually reduced by $10 \%$. In contrast, the number of electronic transactions in the EU in 2017 increased by $7.9 \%$ compared to the previous year, or by $77.86 \%$ compared 
to 2007 . In the same year, payment cards represent the most used banking channel with a share of $52 \%$ in the total number of all transactions. (European Central Bank, 2018).

When it comes to the use of electronic banking channels in Serbia, according to the data available to the National Bank of Serbia, there is an increase in banking channels usage of 5.5\% in 2017 (National Bank of Serbia, 2018). In model defined by Knežević \& Šapić (2018), the impact of legal regulative to the use of electronic trade in Republic of Serbia was examined. Results of conducted research demonstrate that legal framework has positive and significant impact over safety and privacy during the use of e-trade, and that safety and privacy have positive impact on the intensity of e-trade use. Safety, however, has no statistically significant impact on the intensity of e-trade use. In the context of electronic transactions development as well as digital banking channels usage, they propose mutual interaction of state authorities and e-merchants, better information of citizens, as well as better acknowledgement of possibility of online sale by small and medium enterprises.

The goals of this document correlates with the applied research methods and set up hypotheses:

- to determine the difference between the countries of the European Union and Serbia in terms of using the banking channels as measured by the number of transactions completed;

- to identify the major component with the greatest impact on the number of banking branches.

The paper is structured as follows: the introductory part of the paper is followed by a section with a review of the scientific literature, which presents the views and research on the relationship between traditional and digital banking channels. The section Data lists the data sources and the section Methodology describes the scientific methods used in the analysis. This is then followed by the presentation and discussion of the research results, for each multivariate analysis technique respectively applied in the paper. Conclusions are presented at the end of the paper.

\section{Literature review}

Some empirical studies are based on the fact that the traditional banking channel and the digital channel are two independent banking channels, so accordingly, the theoreticians are concerned with their complement-substitute relationship. Researchers that share the opinion that banking channels have complementary relationship support a multi-channel banking trend.

In this regard, the review of the prevailing literature is structured to show studies that have explored (1) the complementary effect between digital and traditional channels (Campbell \& Frei, 2010; Rakita, 2016; Calisir \& Gumussoy, 2008), (2) the substitution 
effect examined through the increased use of electronic transaction devices (Martikainen et al., 2015; Columba, 2009; Drehmann et al., 2002; Hasan et al., 2011; Humphrey et al., 1996).

Applying the statistical analyses of propensity score matching (PSM) over a sample of 80,054 online banking users, Campbell and Frei (2010) concluded that the use of this banking channel has led to an increased number of transactions that occur in the branches. Thus, they concluded that the importance of branches for the users of banking products and services does not decline as a result of digitization, whether there are active, inactive or even passive users, in question. In findings from Rakita (2016), it is mentioned that the positive ratio in using traditional and digital banking channels is present only with active users of products and services, where she states that there is a $60 \%$ probability that the customers using some of the digital banking channels will, at least once a week, use some form of traditional banking service (such as going to the bank counter), more often than the clients who do not use these services at all. Calisir and Gumussoy (2008) focus on internet banking and compare it with other banking channels (phone banking, ATMs, wireless application protocol (WAP), branches, EFT POS terminals and bank branches in stores). The results of their cluster analysis indicate a high level of complementarity between internet banking and branches.

Alternatively, those authors who have dealt with digital technologies are advocating the views on reducing the number of branches as a result of digitalization. The banks in those states directly control the use of digital banking channels through the availability of terminals, and thus indirectly affect the number of branches.

Some authors (Humphrey et al., 1996; Drehmann et al., 2002; Martikainen et al., 2015; Columba, 2009) argue that countries with higher POS availability also have the higher use of electronic payment methods, including payment card transactions. On the other hand, the greater availability of ATMs encourages the use of electronic forms of payment but also influences the increased use of cash, which we associate with the branches. Then again, Hasan et al. (2011) testify to the impact of ATMs on greater success in the bank's operations but also of the reduction in the number of branches.

Taking into account the research conducted regarding the relationship and the impact of digital banking channels on the number of branches, presented in the previous section, it is noted that the banking network is changing its role due to changes in customer preferences over time, as well as due to the modernization of the banking system in the light of the digitalization of the channels for distribution of its services. Accordingly, the hypotheses that will be tested in this research were derived:

H1: The independent variable with the highest factor score from factor 1 (credit card transactions) has the effect of reducing the number of branches.

H2: The independent variable with the highest factor score from factor 2 (direct debit transactions) has the effect of reducing the number of branches.

H3: In countries where factor 1 is high (POS terminal availability and payment card usage), smaller number of branches is obvious. 


\section{Data}

The analysis of the impact of digital banking channels on the presence of branches was carried out for the European Union Member States and Serbia, which makes a total of 29 cases. The data for the European Union, for analysis purposes, were taken from the European Central Bank's database presented in the Payment Transaction Report for 2017 (European Central Bank, 2019). Data for Serbia were collected on the website of the National Bank of Serbia (The National Bank of Serbia, 2018) and those data related to the number of electronic transactions were downloaded from the section Payment system, Statistics part, while data on the number of branches were taken from the quarterly report for the banking sector in Serbia, also for 2017 (IV quarter).

A total of seven variables were used in the study. The first six variables represent independent variables, whose usage is represented over volume of transactions on annually level. The last variable is dependent variable. The overview of the variables is given in Table 1 below.

Table 1. Observed characteristics

\begin{tabular}{|l|l|}
\hline \multicolumn{1}{|c|}{ Variable name } & Description \\
\hline $\begin{array}{l}\text { (1) Electronic } \\
\text { credit transfers }\end{array}$ & $\begin{array}{l}\text { Submissions by telefax or other means, such as automated telephone } \\
\text { banking transformed into electronic payments, standing orders submitted in } \\
\text { paper-based form but executed electronically, credit transfers initiated on } \\
\text { ATM, online transactions performed using banking applications. }\end{array}$ \\
\hline $\begin{array}{l}\text { (2) Debit/delayed } \\
\text { debit card } \\
\text { payments* }\end{array}$ & $\begin{array}{l}\text { Payment transactions performed with cards with a debit or delayed debit } \\
\text { function at a physical terminal or via other channels. } \\
\text { Number of card payments with cards issued by resident PSPs }\end{array}$ \\
\hline $\begin{array}{l}\text { (3) Credit card } \\
\text { payments* }\end{array}$ & $\begin{array}{l}\text { Payment transactions performed with cards with a credit function at a } \\
\text { physical terminal or via other channels. } \\
\text { Number of card payments with cards issued by resident PSPs }\end{array}$ \\
\hline $\begin{array}{l}\text { (4) Direct debit } \\
\text { payments }\end{array}$ & $\begin{array}{l}\text { Payment service, which perform debit on the current account based on the } \\
\text { written consent given by the account holder to the payer. } \\
\text { Number of domestic and cross-border payments }\end{array}$ \\
\hline $\begin{array}{l}\text { (5) POS } \\
\text { transactions }\end{array}$ & $\begin{array}{l}\text { Number of card payments at POS terminals: } \\
\text { at terminals provided by resident PSPs with cards issued by resident PSPs / } \\
\text { issued by non-resident PSPs }\end{array}$ \\
\hline $\begin{array}{l}\text { (6) ATM } \\
\text { transactions }\end{array}$ & $\begin{array}{l}\text { Number of ATM cash withdrawals and cash deposits: } \\
\text { at terminals provided by resident PSPs with cards issued by resident PSPs / } \\
\text { issued by non-resident PSPs }\end{array}$ \\
\hline $\begin{array}{l}\text { (7) Number of } \\
\text { business units- } \\
\text { branches }\end{array}$ & $\begin{array}{l}\text { Number of credit institution's offices legally incorporated in the reporting } \\
\text { country. } \\
\text { Number of branches, exposed counters etc. }\end{array}$ \\
\hline
\end{tabular}

* Except cards with an e-money function only.

Source: the author's overview 
The European Central Bank's Payment Transaction Report lacks a value for the specific variable. Those are:

- Variable 2, missing for Portugal.

- Variable 3, missing for Spain, Italy, Netherlands and Portugal.

- Variable 4, missing for Denmark, Latvia, Lithuania, Estonia, Malta and Finland.

- Variable 5, missing for Malta.

- Variable 6, missing for Finland.

- Variable 7, missing for the United Kingdom.

In such cases, an average value for that variable was calculated and used.

Data processing was done via statistical program.

In order to examine the relationship between variables and differences between countries regarding the use of electronic channels and branches, several methods of multivariate statistical analysis have been used.

\section{Methodology}

In this paper, the first method to be applied onto the data set is an exploratory factor analysis in order to identify the main factors which explain as much variation among the data as possible. The first step in factor analysis is determining the sample size. According to Costello and Osborne (2005), there is a large percentage of researchers (almost one-sixth) applying factor analyses using relatively small samples where ratios are only $2: 1$ or less. They also found that $62.9 \%$ of the researchers performed analyses with subject to item ratios of 10:1 or less, which is still-prevalent rule-of-thumb.

For measuring sampling adequacy, as precondition for factor analysis, the author used standardized Kaiser-Meyer-Olkin (KMO) and Bartlett's test. According to Hair et al. (2010); Pallant (2007); Tabachnick and Fidell (2007), if KMO is greater than 0.6 and the Bartlett's Test of Sphericity (BTS) is significant at $\alpha<.05$, then factorability of the correlation matrix is assumed.

Factor analysis is based on the correlation matrix of the variables involved, the calculation of which is the next step in the paper. This field is also very discussed among the authors. When talking about minimum level of correlation, the coefficient $r$ must be .30 or greater (Tabachnick \& Fidell, 2007). Authors Hair et al. (1995) use different rule-of-thumb for variable categorizing, where \pm 0.30 is minimal, $\pm 0.40 \mathrm{is} \mathrm{im-}$ portant and \pm .50 is practically significant.

Also, decision on the number of factors can be made considering different criteria. The most used is latent root method, which includes factors that have eigenvalue greater than 1 (Kaiser's criterion, 1960) (find in Yong \& Pearce, 2013; Braeken \& Van 
Assen, 2016). According to authors Velicer \& Jackson (1990) and Hayton et al. (2004), there are alternative and more reliable methods such as Cattell's (1966) scree test, Velicer's MAP criteria and parallel analysis (PA). Considering the goals of this research, the author decided to base the decision regarding number of factors on Kaiser's criterion.

The extraction of the common factors was done using the Principal Component Analysis method within Factor analysis. It is a simple technique used for variable reduction by creating combinations that retain as much of the original measures' variance as possible (Conway \& Huffcutt, 2003; Schmitt, 2011). In order to make the implication of each factor clearer, they must be rotated. In theory and praxis exist several models, and they fall in two categories: orthogonal and oblique. In this paper, the author decided to apply Obligue method - Direct Oblimin, bearing in mind that between different kinds of digital channels, is always some kind of correlation, even low.

Factor analysis is calculated to reduce the number of variables which are then subject to multiple linear regression method. The multiple regression analysis was used in the study to describe the relationship between one dependent variable and multiple independent variables. Independent variables with the highest impact factor (factor loading) were previously extracted from each identified factor.

Before setting the equation and applying the regression analysis in this paper, it is necessary to examine the presence of multicolinearity between variables of the model. Multicollinearity occurs between the independent variables that are used to predict the dependent variable in the analysis results. In that sense, the author performed Variance Inflation Factor (VIF) test, as well as Tolerance (TOL) test on Factor 1 and Factor 2. The variables whose VIF values are greater than 10 should not be included in the model. Also, the value of TOL should be higher than 0.1 (Lin, 2008; Račić \& Barjaktarović, 2016; Salmerón Gómez et al., 2016).

Another element that was checked is autocorrelation between independent variables. Durbin-Watson test is used for this purpose. If condition of $1.60<\mathrm{d}<2$, the first order autocorrelation is not present. For a small sample, some authors suggest the ruleof-thumb $1<\mathrm{d}<2.25$ (Wang \& Jain, 2003).

By obtaining the regression coefficients, it will be possible to deduce in which independent variables the regression is present when it comes to affecting the number of branches.

\section{Results and discussion about the results}

In the following section, the author presents findings from the survey according to the methodology in the previous section, respectively. 
Factor analysis is applied on 6 independent variables using 29 items, which is nearly a proportion of $6: 1$. It can be concluded that the sample size in this analysis is acceptable.

Calculated KMO is .735. Bartlett's test shows value of 262.497 , with $\mathrm{df}=15$ and Sig .000. These results confirm that the sample is adequate and provide minimum standards for performing factor analysis (Hair et al., 2010; Pallant, 2007; Tabachnick \& Fidell, 2007).

Correlation matrix showed that the minimum level of correlation condition between all variables included in the model is satisfied (Tabachnick \& Fidell, 2007). Bearing this fact in mind, the author kept all variables in the model. They are shown in Table 2 below.

Table 2. Correlation matrix

\begin{tabular}{|c|c|c|c|}
\hline \multicolumn{4}{|c|}{ Fornell-Larcker } \\
\hline & Employee_CSR & Envi_Perf & Fin_Perf \\
\hline Employee_CSR & 0.890 & & \\
\hline Envi_Perf & 0.633 & 0.949 & \\
\hline Fin_Perf & 0.403 & 0.572 & 0.841 \\
\hline \multicolumn{4}{|c|}{ HTMT } \\
\hline & Employee_CSR & Envi_Perf & Fin_Perf \\
\hline \multicolumn{4}{|l|}{ Employee_CSR } \\
\hline Envi_Perf & 0.701 & & \\
\hline Fin_Perf & 0.425 & 0.637 & \\
\hline
\end{tabular}

After all prerequisites for applying factor analysis had been fulfilled met, the author performed calculation of the model.

Factor analysis identified two factors, of which the eigenvalues and percentage of data variations are shown in Table 3. For both factors, the eigenvalues are bigger than 1 (Kaiser's criterion, 1960). For factor 1 , the eigenvalue is 4.54 , while for factor 2 it is 1.146 , implying that factor 1 has a more significant effect on differences between countries.

The factors cumulatively explain $94.77 \%$ of the variation in the data in comparison to the raw data. In other words, a total of $94.77 \%$ of variations used in the banking channels (the number of transactions on different banking channels) in the countries of the European Union and Serbia will be explained by two factors. Considering that the share of the first major component in the total variance is $75.67 \%$, it follows that majority of the variations in data are explained with factor 1. Factor 2 explains only $19.10 \%$ of data variations. For the purposes of this paper, the author kept both factors. 
Table 3. Eigenvalues and percentage of data variations

\begin{tabular}{|c|c|c|c|c|}
\hline Factor & \multicolumn{3}{|c|}{ Initial Eigenvalues } \\
\hline & Total & \% of Variance & Eigenvalue Cumulative & Cumulative \% \\
\hline 1 & 4.540 & 75.665 & 4.540 & 75.665 \\
\hline 2 & 1.146 & 19.101 & 5.686 & 94.766 \\
\hline
\end{tabular}

Source: Author's calculation

From the two extracted factors, it is necessary to identify the variables with the highest impact factor. Factor loadings are shown in Table 4 below. The presented values are sorted by size and higher than 0.5 .

Table 4. Pattern Matrix ${ }^{a}$

\begin{tabular}{|l|c|c|}
\hline & \multicolumn{2}{|c|}{ Component } \\
\hline & 1 & 2 \\
\hline Credit card payments & $\mathbf{1 . 0 5 5}$ & \\
\hline POS transactions & 0.905 & \\
\hline Debit/delayed debit card payments & 0.896 & $\mathbf{0 . 9 7 7}$ \\
\hline Direct debit payments & & 0.963 \\
\hline Electronic credit transfers & & 0.616 \\
\hline ATM transactions & & \\
\hline
\end{tabular}

Extraction Method: Principal Component Analysis.

Rotation Method: Oblimin with Kaiser Normalization. ${ }^{\text {. }}$

a. Rotation converged in 6 iterations.

\section{Source: Author's calculation}

Factor 1 has a high positive loading on the following variables: credit card transactions (1.055), debit/delayed debit card transactions (.896) and POS transactions (.905). Loading for variable credit card transactions exceeds 1 , which is a typical situation when using Direct oblimin and Pattern matrix. This is also a variable with highest impact factor within factor 1.

Factor 2 has high loading on the following variables: direct debit transactions (.977), electronic credit transfers (.963) and ATM transactions (.616). The one that has the highest factor loading is direct debit transactions.

Factor analysis findings have shown that factor 1 has a high load of POS transactions and payment card variables, on the basis of which these three banking instruments are brought into complementary relationship. These findings support Hypothesis 3, which is consistent with the findings of Humphrey et al. (1996); Drehmann et al. (2002); Martikainen et al. (2015) and Columba (2009).

This shows that the biggest differences in countries are primarily the result of different use of credit cards and subsequently differences in debit direct transactions.

An overview of factor scores by countries is given in Table 5 below. 
Table 5. Factor scores by countries

\begin{tabular}{|c|c|c|}
\hline & \multicolumn{2}{|c|}{ Factor Scores } \\
\hline & Factor 1 & Factor 2 \\
\hline \multicolumn{3}{|l|}{ Belgium } \\
\hline Bulgaria & -0.4805 & -0.5981 \\
\hline Czech Republic & -0.3078 & -0.3314 \\
\hline \multicolumn{3}{|l|}{ Denmark } \\
\hline Germany & & 4.1874 \\
\hline Estonia & -0.4772 & -0.3640 \\
\hline Ireland & & -0.4831 \\
\hline Greece & -0.3434 & -0.4739 \\
\hline Spain & & 0.5019 \\
\hline France & 1.6506 & 1.9810 \\
\hline Croatia & -0.4513 & -0.5236 \\
\hline \multicolumn{3}{|l|}{ Italy } \\
\hline Cyprus & -0.4921 & -0.6354 \\
\hline Latvia & -0.4990 & -0.3549 \\
\hline Lithuania & -0.4840 & -0.3516 \\
\hline Luxembourg & -0.4352 & -0.6310 \\
\hline Hungary & -0.3528 & -0.4923 \\
\hline Malta & -0.3600 & -0.4136 \\
\hline The Netherlands & & 0.4440 \\
\hline Austria & -0.3355 & \\
\hline Poland & 0.3654 & 0.3378 \\
\hline Portugal & & -0.3651 \\
\hline Romania & -0.3635 & -0.4995 \\
\hline Slovenia & -0.4761 & -0.5754 \\
\hline Slovakia & -0.4326 & -0.4883 \\
\hline \multicolumn{3}{|l|}{ Finland } \\
\hline \multicolumn{3}{|l|}{ Sweden } \\
\hline United Kingdom & 4.6715 & 1.3024 \\
\hline Serbia & -0.4627 & -0.5722 \\
\hline
\end{tabular}

Source: Author's calculation

The signs of the loadings show the direction of the correlation and do not affect the interpretation of the magnitude of the factor loading or the number of factors to retain (Kline, 1994). Values with sign (-) show opposite direction from the factor they belong to.

For some countries in Table 5, there are no values. Tabachnick and Fidell (2001) cite .32 as a good rule of thumb for the minimum loading of an item, which equates to approximately $10 \%$ overlapping variance with the other items in that factor. Countries with loadings lower than .32 are excluded from the table. 
Based on the analysis of country-by-country factor scores, it is noted that the loading for factor 1 is very strong for the United Kingdom (4.67), which means that this country bestows importance on credit card transactions. The UK Banking Practice Report for 2018 (UK Finance, 2018) states that credit card use has exceeded the cash use (which has been attributed to the branches) for the first time. In France, credit card usage is also high (1.6506). For other countries, loadings go from -0.30 to -0.57 based on which it can be concluded that the number of transactions on digital channels is a on much lower level and that is why loadings have opposite direction for this factor.

Germany certainly stands out for its significant number of direct debit payments. It should therefore come as no surprise that factor 2 is much more loaded in Germany than in other countries. Also, France and United Kingdom have slightly lower factor scores than Germany, but these scores are at a much higher level in comparison to other countries. France stands out from other countries because of its relatively equal level of loadings for both factors. However. United Kingdom differs because of its high loading for factor 1 and smaller loading for factor 2 .

Looking at the factor loadings for Serbia, it is a fact that both are with negative signs (-0.4627 and -0.5722). Loadings are similar for factor 1 and factor 2 in countries of the former member state of the Socialist Federal Republic of Yugoslavia (SFRJ) which are Croatia (-0.4513 and -0.5236) and Slovenia (-0.4761 and -0.5754).

Bearing in mind that the increasing preference of users towards digital channels reflects in a sense the decline in the influence and importance of branches in the banking market, and consequently the decline in their prevalence, in this part of the document, the emphasis is placed on examining the existence and strength of this connection. For this purpose, the multiple linear regression method was used. Two independent variables (credit card use and direct debit usage) were taken into the model, on the basis of factor analysis, while the number of branches remained the dependent variable. The aim of the analysis process is to omit the influence of variables that are not so dominant in the group, that is, to focus on those variables that best reflect the differences of the countries surveyed in the banking market.

The factor analysis reduced the total of 7 characteristics to only 2 major variables (factors) that will be used for additional data analysis, through regression analysis. In that sense, the author examined the existence of multicollinearity between those variables. This was done using VIF and TOL analysis.

The results are shown in Table 6 below.

Table 6. Checking the existence of multicollinearity in the model

\begin{tabular}{|l|l|c|c|}
\hline Model & & Tolerance & VIF \\
\hline 1 & Credit card payments & 0.890 & 1.123 \\
\hline 2 & Direct debit payments & 0.890 & 1.123 \\
\hline
\end{tabular}

a. Dependent Variable: Number of branches 


\section{Source: Author's calculation}

We conclude that VIF and TOL values for both Factors are in defined ranges, which means that there is no existence of multicollinearity and that Factors can be included in the model. These results are already confirmed in the papers of authors Lin (2008), Račić and Barjaktarović (2016), Salmerón Gómez et al. (2016).

Also, Durbin-Watson test shows that there is no autocorrelation between factors. Its value is 1.452. Considering the fact that this is a small sample, the result is in the limits (Wang \& Jain, 2003). The result is shown in Table 7 below.

Table 7. Checking the existence of autocorrelation in the model ${ }^{b}$

\begin{tabular}{|l|c|}
\hline Model & Durbin-Watson \\
\hline 1 & $1.452^{\mathrm{a}}$ \\
\hline
\end{tabular}

a. Predictors: (Constant), Credit card payments, Direct debit payments

b. Dependent Variable: Number of branches

\section{Source: Author's calculation}

Before exploring the digital channels influence on branches, in the chart is shown usage trend of these three variables, namely, two independent variables representing the factors with influence, and the dependent variable.

Chart 1. Comparative overview of the use of banking channels by country

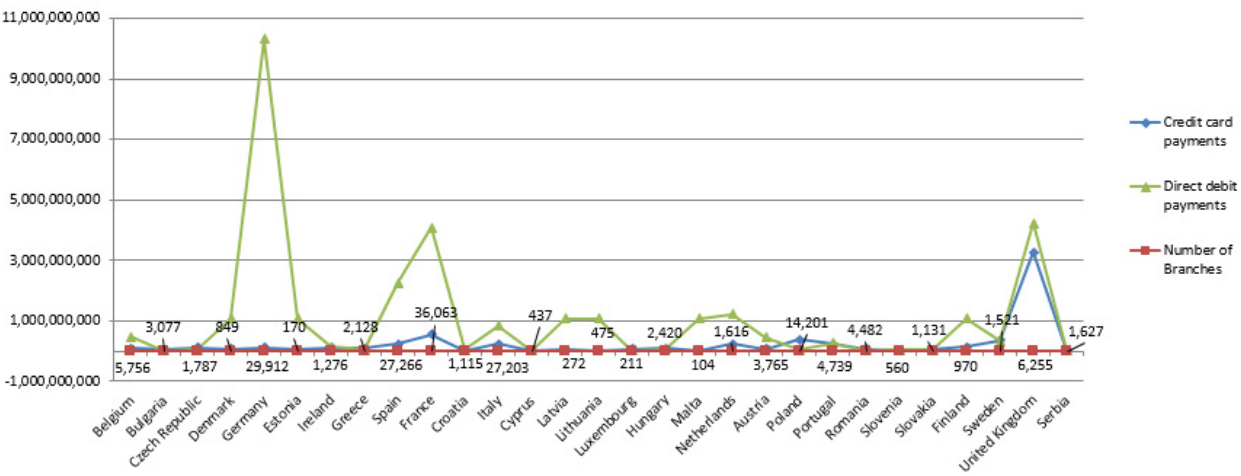

Source: Author's calculation

In Chart 1 above, a comparative overview of the use of two digital channels versus number of branches, observed in the countries of the European Union and Serbia. The first independent variable - number of credit card transactions - is highlighted in blue on the chart, while the second independent variable - number of direct debit transactions - is highlighted in green. The number of branches is shown in red and they are right next to the abscissa, due to very low values compared to the number of credit card transactions and direct debit. This is why the branch number information is visible in the chart itself. 
Looking at the relationship between the first independent variable with the highest factor loadings within the factor 1 and the number of branches, we note the following in the chart: countries with high level of credit card payments are also countries with an average number of branches. All other countries have middle or lower level of credit card payments but above-average number of branches. United Kingdom has a higher number of credit card transactions than other European Union countries or Serbia, and an average number of branches. This country has the highest factor score for factor 1. On the contrary, France, Spain and Italy have middle level of credit card payments, but among the highest number of branches in European Union.

Looking at the relationship between the second independent variable and the number of branches, we note the following in the chart. Countries with high level of direct debit channel usage are also countries with a large number of branches. All other countries have middle or lower level of direct debit usage and only a couple of thousands of branches or less. For example, Germany, France, Spain and United Kingdom belong to the first group-group with high level of direct debit transactions and number of branches. These were the countries that had the highest factor score for factor 2 . These countries are the most developed in European Union.

Serbia has small values for both independent variables in relation to other European Union countries. When comparing credit card channel usage in Serbia, there are Croatia, Malta and Slovenia with lower level of transactions, which is confirmed by their similar loadings. Bulgaria is only country with lower level of direct debit channel usage comparing to Serbia.

Results of regression analysis are presented in Table 8 below.

Table 8. Regression model ${ }^{a, b}$

\begin{tabular}{|c|c|c|c|c|c|}
\hline \multicolumn{6}{|c|}{$\begin{array}{l}\mathrm{R}=.646^{\mathrm{a}} / \mathrm{R} \text { Square }=0,417 \text { / Adjusted R Square }=0,372 \\
\text { Std. Error of the Estimate }=8079.447\end{array}$} \\
\hline & $\mathrm{B}$ & Std. Error & Beta & $\mathrm{t}$ & Sig. \\
\hline (Constant) & 3041.990 & 1730.682 & & 1.758 & 0.091 \\
\hline Credit card payments & $-1.378 \mathrm{E}-06$ & 0.000 & -0.081 & -0.508 & 0.615 \\
\hline Direct debit payments & $3.268 \mathrm{E}-06$ & 0.000 & 0.668 & 4.210 & 0.000 \\
\hline
\end{tabular}

a. Predictors: (Constant), Direct debit payments, Credit card payments

b. Dependent variable: Number of branches

Source: Author's calculation

The regression model can also be represented by the equation number 1 (Hosmer et al., 2000):

$$
\mathrm{y}=\mathrm{b} 0+\mathrm{bi} 1 * \mathrm{X} 1
$$

from which were derived equations 2 and 3 with two independent variables: 


$$
\begin{gathered}
\mathrm{y}=\mathrm{b}_{0}+\mathrm{b}_{\mathrm{i} 1} * \mathrm{X}_{1}+\mathrm{b}_{\mathrm{i} 2} * \mathrm{X}_{2} \\
\mathrm{y}=3041.990+(-0.000001378179) * \mathrm{X}_{1}+0.000003267580 * \mathrm{X}_{2}
\end{gathered}
$$

The $\mathrm{X} 1$ parameter used in this model is the first factor and it is credit card payments and the X2 parameter in this model is another factor, namely, direct debit payments.

Free member $\mathrm{B}_{0}$ (Intercept) shows the expected value of the dependent variable if the independent variables are 0 . In this case, the free member is 3041.990 , so it can be concluded that the number of branches would be 3.041 if the number of credit card transactions and the number of direct debit transactions fell to 0 , that is, if the banks would stop to use these banking channels.

The correlation coefficient (R), which shows the level of linear connection between the dependent and independent variables, has a value of $64.6 \%$, indicating a medium-strength relationship between these variables. This is confirmed by the beta indicators from Table $8\left(\mathrm{~B}_{1}\right.$ and $\left.\mathrm{B}_{2}\right)$, with values 0.000001378179 for the first variable and 0.000003267580 for the second variable, respectively. The results show that $41.7 \%$ of the variations in the number of branches $\mathrm{R}^{2}$ are explained by a linear relationship between the dependent variable and the two independent variables.

Parameter testing is performed by comparing the p-value from the last column for each independent variable with level of risk $(\alpha=0.05)$.

Variable $\mathbf{X}_{1}$ has a p-value of 0.615 , that is, a value greater than the defined level of risk, implying that the use of credit cards has no significant effect on the number of branches. Hypothesis 1 is declined.

Variable $\mathbf{X}_{2}$ has a p-value of 0.000 , and is a statistically significant variable because the level of risk is less than 0.05 . Direct debit transactions have been found to have an impact on the number of branches. Hypothesis 2 is confirmed.

\section{Conclusion}

Based on the results of the conducted research, it can be concluded that all the goals defined at the beginning of the paper were achieved.

The methods used in the document clearly illustrate the state and level of development of the European Union member states and Serbia regarding the use of banking channels. Also, the relationship between banking channels in the mentioned countries was identified, and the influence of the two most significant digital channels (two factors) on the number of traditional banking channel-branches, was examined.

(1) The results of factor analysis show that two factors reflect $94.766 \%$ of the variation in the use of banking channels. The variable that explains the majority of dif- 
ferences between countries is representative for factor 1 and it is credit card transactions. Variable from the second factor is direct debit transactions. Further analysis revealed that factor 1 was expressed primarily in the United Kingdom and then in France. Factor 2 dominates in France, Germany, Spain and United Kingdom.

Countries with above average POS terminal availability and payment card usage have average or smaller number of branches, which coincide with results in other empirical studies shown in this paper. Countries with high level of direct debit channel usage are also countries with a large number of branches. All other countries have middle or lower level of direct debit usage and only a couple of thousands of branches or less.

(2) The multiple regression method demonstrated the presence of a strong correlation between the independent variable from the factor 2, which is usage of the direct debit banking channel, and the number of branches, considering that this independent variable explains a significant percentage of variations in the number of branches. The relationship between factor 1 and the dependent variable is negative and strong, which leads to a smaller effect of factor 1 on branch variability. The result shows correlation with studies regarding substitutive relationship between channels.

Although there is a downward trend in the number of branches in Europe, as a result of the digitalization of banking channels and the ongoing review of bank efficiency, they will not disappear. The DBR Media LLC research results show that, despite these trends, branches continue to be built. In fact, in this year's survey, $41 \%$ of financial executives responding indicated that they will be increasing their branch network in 2017, which is $6 \%$ higher than in 2016. When it comes to the branches in Serbia, banks should expect change in the way that branches work with clients, as well as a reorientation of their business to products sales. Transaction services will increasingly move to digital banking channels. As a result of the merger of banks, which has been active in the last few years in the banking market in Serbia, branches are being closed; however, there is still insufficient use of digital banking channels to attribute branch closure to the consequence of their use.

\section{References}

Amromin, G., \& Chakravorti, S. (2009). Whither Loose Change? The Diminishing Demand for Small-Denomination Currency. Journal of Money, Credit and Banking, 41(2/3), 315-335. Doi: https://doi.org/10.1111/j.1538-4616.2009.00207.x

Bergendahl, G., \& Lindblom, T. (2007). Pricing of Payment Services: A Comparative Analysis of Paper-based Banking and Electronic Banking. The Service Industries Journal, 27(6), 687-707. Doi: https://doi.org/10.1080/02642060701453148

Braeken, J., \& van Assen, M. A. (2017). An empirical Kaiser criterion. Psychological Methods, 22(3), 450-466. Doi: https://doi.org/10.1037/met0000074 
Byers, R. \& Lederer, P. (2001). Retail Bank Services Strategy: A Model of Traditional, Electronic, and Mixed Distribution Choices. Journal of Management Information Systems, 18(2), 133-156. Doi: https://doi.org/10.1080/07421222.2001.11045686

Calisir, F., \& Gumussoy, C.A. (2008). Internet banking versus other banking channels: Young consumers' view. International Journal of Information Management, 28(3), 215-221. Doi: https://doi.org/10.1016/j.ijinfomgt.2008.02.009

Campbell, D., \& Frei, F. (2010). Cost structure, customer profitability and retention Implications of self-service distribution channels: Evidence form customer behavior in an online banking channel. Management Science, 56(1), 4-24. Doi: https://doi.org/10.1287/mnsc.1090.1066

Conway, J. M., \& Huffcutt, A. I. (2003). A review and evaluation of exploratory factor analysis practices in organizational research. Organizational research methods, $6(2)$, 147-168. Doi: https://doi.org/10.1177/1094428103251541

Columba, F. (2009). Narrow money and transaction technology: New disaggregated evidence. Journal of Economics and Business, 61(4), 312-325. Doi: https://doi.org/10.1016/j.jeconbus.2009.01.001

Costello, A. B., \& Osborne, J. (2005). Best practices in exploratory factor analysis: Four recommendations for getting the most from your analysis. Practical assessment, research, and evaluation, 10(7), 1-10. Doi: https://doi.org/10.7275/jyj1-4868

DBR Media LLC. (2017). Digital Banking Report: Financial Marketing Trends 2017, 248. Brecksville, Ohio.

dos Santos, P.L., \& Kvangraven, H. (2017). Better than Cash, but Beware the Costs: Electronic Payments Systems and Financial Inclusion in Developing Economies. Development and Change, 48(2), 205-227. Doi: https://doi.org/10.1111/dech.12296

Drehmann, M., Goodhart, C., Krueger, M., Boldrin, M., \& Rose, A. (2002). The Challenges Facing Currency Usage: Will The Traditional Transaction Medium Be Able To Resist Competition From The New Technologies? Economic Policy, 17(34), 195-227. Doi: https://doi.org/10.1111/1468-0327.00087

European Central Bank. (2018). Payment statistics:2017. Retrieved July 26, 2019, from https://www.ecb.europa.eu/press/pr/stats/paysec/html/ecb.pis2017.en.html

European Central Bank. (2019). Payment statistics. Retrieved July 26, 2019, from https://sdw.ecb.europa.eu/reports.do?node $=1000004051$

Hair, J. F., Anderson, R. E., Tatham, R. L., \& Black, W. C. (1995). Multivariate date analysis with readings. Englewood Cliff, NJ: Prentice. 
Hasan, I., Schmiedel, H., \& Song, L. (2012). Returns to retail banking and payments. Journal of Financial Services Research, 41(3), 163-195. Doi: https://doi.org/10.1007/s10693-011-0114-y

Hayton, J. C., Allen, D. G., \& Scarpello, V. (2004). Factor retention decisions in exploratory factor analysis: A tutorial on parallel analysis. Organizational research methods, 7(2), 191-205. Doi: https://doi.org/10.1177/1094428104263675

Holland, C.P.; Lockett, A.G.; \& Blackman, I.D. (1998). Global strategies to overcome the spiral of decline in universal bank markets. Journal of Strategic Information Systems, 7(3), 217-232. Doi: https://doi.org/10.1016/S0963-8687(98)00029-8

Hosmer Jr, D. W., Lemeshow, S., \& Sturdivant, R. X. (2013). Applied logistic regression, 398 (2nd ed.). New York: John Wiley \& Sons.

Howcroft, B., \& Beckett, A. (1996). Branch networks and the retailing of high credence products. International Journal of Bank Marketing, 14(4), 3-11. Doi: https://doi.org/10.1108/02652329610119274

Humphrey, D.B.; Pulley, L. B., \& Vesala, J.M. (1996). Cash paper and electronic payments: A cross country analysis. Journal of Money, Credit and Banking, 28(4), 914939. Doi: https://doi.org/10.2307/2077928

Jagtiani, J., \& Lemieux, C. (2018). Do fintech lenders penetrate areas that are underserved by traditional banks? Journal of economics and business, 100, 43-54. Doi: https://doi.org/10.1016/j.jeconbus.2018.03.001

King, B. (2010). Bank 2.0: How customer behaviour and technology will change the future of financial services. Marshall Cavendish International Asia Pte Ltd.

Kline, P. (1994). An easy guide to factor analysis 1st Edition. London: Routledge.

Knežević, M., \& Šapić, S. (2018). Legal regulation and usage of electronic trade in Republic of Serbia. Ekonomika, 64(3), 1-22.

Lin, F. J. (2008). Solving Multicollinearity in the Process of Fitting Regression Model Using the Nested Estimate Procedure. Quality and Quantity Volume, 42(3), 417-426. Doi: https://doi.org/10.1007/s11135-006-9055-1

Martikainen, E., Schmiedel, H., \& Takalo, T. (2015). Convergence of European retail payments. Journal of Banking and Finance, 50, 81-91. Doi:

https://doi.org/10.1016/j.jbankfin.2014.09.021

Morris, J. L. \& Simoff, P. (2013). Time to close underperforming branches? Bankers need sharp shears, applied with care. ABA Banking Journal, 105(1), 14-17.

Moutinho, L., Davies, F., Deng, S., Peris, S.M., \& Alcaniz, E. B. (1997). The future role of bank branches and their managers: comparing managerial perceptions in Cana- 
da and Spain. International Journal of Bank Marketing, 15(3), 99-105. Doi: https://doi.org/10.1108/02652329710166019

Narodna Banka Srbije. (2018). Opšti pokazatelji funkcionisanja platnih sistema Narodne banke Srbije-Transakcije sa i bez platnog naloga. Retreived January 15, 2019, from https://www.nbs.rs/internet/latinica/35/statistika/index.html

Nitescu, D. C. (2015). Banking Business and Social Media - A Strategic Partnership. Theoretical and Applied Economics, 22(4), 121-132.

Rakita, A. (2016). Kanali distribucije bankarskih proizvoda i usluga u savremenom poslovnom okruženju. Marketing, 47(1), 66-77. Doi:

https://doi.org/10.5937/markt1601066R

Račić, Ž., \& Barjaktarović, L. (2016). Analiza empirijskih determinanti kreditnog rizika u bankarskom sektoru Republike Srbije. Bankarstvo, 45(4), 94-109. Doi:

https://doi.org/10.5937/bankarstvo1604094R

Salmerón Gómez, R., García Pérez, J., López Martín, M. D. M., \& García, C. G. (2016). Collinearity diagnostic applied in ridge estimation through the variance inflation factor. Journal of Applied Statistics, 43(10), 1831-1849. Doi:

https://doi.org/10.1080/02664763.2015.1120712

Schmitt, T. A. (2011). Current methodological considerations in exploratory and confirmatory factor analysis. Journal of Psychoeducational Assessment, 29(4), 304-321. Doi: https://doi.org/10.1177/0734282911406653

Sousa, R., Amorim, M., Rabinovich, E., \& Sodero, A.C. (2015). Customer use of Virtual Channels in Multichannel Services: Does type of activity matter? Decision Sciences, 46(3), 623-657. Doi: https://doi.org/10.1111/deci.12142

Tabachnick, B. G., \& Fidell, L. S. (2007). Using multivariate statistics, 5th edition. Boston: Allyn and Bacon

Velicer, W. F., \& Jackson, D. N. (1990). Component analysis versus common factor analysis: Some issues in selecting an appropriate procedure. Multivariate behavioral research, 25(1), 1-28. Doi: https://doi.org/10.1207/s15327906mbr2501_1

Wang, G. C., \& Jain, C. L. (2003). Regression analysis: modeling \& forecasting. New York: Graceway Publishing Company.

Yakhlef, A. (2001). Does the Internet Compete with or Complement Bricks-and-Mortar Bank Branches? International Journal of Retail \& Distribution Management, 29 (6), 272-281. Doi: https://doi.org/10.1108/09590550110393965

Yong, A. G., \& Pearce, S. (2013). A beginner's guide to factor analysis: Focusing on exploratory factor analysis. Tutorials in quantitative methods for psychology, 9(2), 7994. Doi: https://doi.org/10.20982/tqmp.09.2.p079 